\title{
ERGONOMIC ANALYSIS OF DENTAL TREATMENTS TASKS: DISCOMFORT FACTOR IDENTIFICATION AND IMPACT ON BODY REGIONS
}

\author{
Müge HANEFİĞLU1 ${ }^{1}$, Orhan KORHAN 2* \\ ${ }^{1}$ Endüstri Müh. Böl., Doğu Akdeniz Üniversitesi, Gazimağusa, 99628, KKTC, E-posta: mugehanefioglu@gmail.com \\ 2 Endüstri Müh. Böl., Doğu Akdeniz Üniversitesi, Gazimağusa, 99628, KKTC. \\ E-posta: orhan.korhan@emu.edu.tr, ORCID No: https://orcid.org/0000-0002-9388-8605
}

Makale Geliş : 25.07 .2017

Makale Kabul : 21.12.2017

Araștırma Makalesi

\section{Diş Tedavisindeki Hareketlerin Ergonomik Analizi: Rahatsızlık Sebeplerinin Tespiti ve Vücut Bölgelerine Etkisi}

Öz

Diş hekimliği mesleği, uzun süreli statik kas yüklemesi, yüksek oranda tekrarlanan ve monoton çalışma, dokuların kuvvetle zorlanması veya mekanik olarak sıkıştırılması ve titreșimli araçların kullanılmasını içerir. $\mathrm{Bu}$ nedenle diș hekimlerinin, maruz kaldıkları mesleki kas-iskelet rahatsızlıkları (MKISR) yüzünden maliyetli sağlık sorunları yaşayarak erken emekli olmaları söz konusudur. Bu çalışmanın amacı dişhekimlerinin yaşamakta olduğu kas iskelet sistemi rahatsızlıklarının risk faktörlerini tanımlamak ve bölgesel olarak tespit edip, etki derecelerini incelemektir. Bu çalışma kapsamında bir anket hazırlanmış olup, çeşitli üniversitelerin, hastahanelerin ve diș kliniklerinde görev yapan 67 dișhekimi tarafindan doldurulmuştur. Diş hekimlerinin altı vücut bölgesine en yaygın tedavi yöntemleri esnasında EMG ölçümleri yapılmıştır. İstatistiksel olarak anlaml ve MKISR'nın oluşmasina sebep olan faktörleri belirlemek amaciyla Diskriminant Analiz yöntemi kullanılmıștır. EMG deneyinden elde edilen sonuçlarl ise ANOVA kullanılarak belirlenen MKISR faktörleri teyit edilmiştir. Diş hekimlerinin tedavi esnasında en sik rastlanan pozisyon statik ve uzun süreli oturma / durma pozisyonda oldukları tespit edilmiştir. Son 12 ayda yaşanan kas iskelet sistemi rahatsızlıklarının en çok görülmekte olduğu bölgeler boyun, el/bilek, üst sirt, ve omuzlar olarak saptanmıștır. Son 7 günde ise en çok dirsek, ayaklar, kalça, ve bilek/el bölgelerinde rahatsızlık yașandığı tespit edilmiştir. Diș hekimlerinin uygulamakta olduğu endodonti, dolgu, diş çekimi, muayene, ve çıkarılabilir protez tedavilerinin, vücut bölgeleriyle etkileşerek kas-iskelet sistemi rahatsızlıklarına yol açtığı ortaya çıkmıştır. Ancak, vücut bölgesi diş çekimi, endodonti ve diș muayenesi esneasında oluşabilecek tek anlamlı risk faktörü olarak bulunmuştur.

Anahtar Kelimeler : Kas-iskelet rahatsızlıkları, Diş hekimi, Diş tedavisi, Elektromiyogram
Article Received : 25.07.2017

Article Accepted: 21.12.2017

Research Article

\section{Ergonomic Analysis of Dental Treatments Tasks: Discomfort Factor Identification and Impact on Body Regions}

\begin{abstract}
Dentistry profession involves in prolonged static muscle loads, highly repetitive and monotonous work, high force exertion or mechanical compression of tissues, and using vibrated tools. Therefore dentists are exposed to work-related musculoskeletal disorders (WRMSDs), which results in costly health problems and early retirements. This research aims to determine the risk factors of musculoskeletal discomforts among dentists, and to identify the impact of the dental tasks on the body regions during particular treatments. A questionnaire is created and fulfilled by 67 dentists from universities, hospitals, and dental offices. Electromyography studies were applied on six body regions of randomly selected three dentists during most common dental treatments. Discriminant Analysis was applied to determine whether a set of variables is effective in predicting category membership, and to identify statistically significant factor(s) which contribute(s) formation of the WRMSDs. ANOVA was utilized to analyze the results which were obtained from sEMG experiment and to determine the risk factors of work related musculoskeletal disorders. The most common position of the dentists while performing their profession was static and prolonged sitting / standing position. Musculoskeletal discomforts were experienced during the past 12 months in neck, hand / wrist, upper back, and shoulder regions; and during the past 7 days in elbows, feet, hip, and wrist / hand regions. There is no significant factor on dental filling therapy, tooth cleaning, fixed prosthodontics, and removable prosthodontics treatments. However, body region is the only significant factor on tooth extraction, endodontic and dental examination treatments.
\end{abstract}

Keywords : Musculoskeletal discomfort, Dentists, dental task, Electromyogram.

\footnotetext{
${ }^{*}$ Corresponding author ; Tel : 0.392.630 1318
} 


\section{Introduction}

Musculoskeletal disorders can be affected by wrong, awkward positions and forceful, repetitive movements for human body. These disorders can be seen in several body parts such as neck, back, shoulders, elbows, knees, hand, wrists, hips, and fingers which associate with daily life and profession. Mostly, discomforts can be shown by occupation. First step of protecting human health is awareness and consciousness.

Despite of technological advances, many occupational health problems still persist in modern dentistry. These include percutaneous exposure incidents (PEI); exposure to infectious diseases (including bioaerosols), radiation, dental materials, and noise; musculoskeletal disorders; dermatitis and respiratory disorders; eye injuries; and psychological problems (Leggat et al., 2007).

Workplace conditions, organizational, psychosocial and socio cultural variables incline the work related musculoskeletal disorders (Khan and Chew, 2013). Prolonged static muscle loads, highly repetitive and monotonous work, high force exertion or mechanical compression of tissues, are using vibrated tools are highly shown in dentistry. High job stress and non-work related stress reactions are also associated to upper extremity musculoskeletal disorders.

Dentistry includes repetitive movements, visual acuity, extreme static postures and force exertion. Neck and upper limbs disorders demonstrated as common disorders among dentists. Musculoskeletal disorders are greatly seen because of number of potential risk factors such as constrained postures, positions close to extremes, steep forward bending of the head, repetitive movements, high static muscle and joint load, and lack of pauses. As a result of experiencing stress and repetitive activities, discomfort can be seen. Neck, back and shoulder or arm pain (81\%) are the common disorders among dental operators (Nutalapati et al., 2009). Costly health problems and early retirements can also occur as a result of these improper and stressful working conditions.

The aim of this study is to investigate the occurrence of musculoskeletal discomfort among dentists. When they were treating patient, their bodies are studied in order to obtain statistical data according to muscle groups which are used based on determined tasks.

In this study, a questionnaire is used to collect personal information and socio demographic data of dentists and ergonomic risk factors which affect performance are determined. Then, six muscles activities are taken by surface electromyography (sEMG) according to determined job tasks which are attached to dentists while operating. This study is designed to reveal the musculoskeletal discomfort among dentists during the most common treatments in their profession, which has not been considered in the literature so far.

\section{Literature Review}

Musculoskeletal disorders affects human life such as reduce productivity and early retirement. Risk factors are revealed such as static and awkward posture and work practices contribute to long term health problems among dentists.

Dentists' health and their career may be related with occupational risk factors and permanent pain. Their work area is limited and it can cause neck, and back problems for them. On the other hand, dentists' posture and their work habits are also affect their health conditions. While dentists are treating patients, back pain, arm abduction, cervical spine flexion, and back/neck/shoulder rotation are found (Finsen et al., 1997).

Observations of Rolander et al. (2005) showed that dentists generally perform their clinical work in a sitting position, with the head bent forward almost half of the time. They found only weak to moderate correlations ( $\mathrm{r}$ $=0.0-0.6$ ) between observed physical work load and subjective estimations of experienced physical work load and musculoskeletal complaints.

Mechanical injuries can affect dentist's tissues while scaling and drilling operation. Hearing loss may occur with high speed drills and ultrasonic scalars among dentists. Vibrating tools are harmful and may cause carpal tunnel syndrome (CTS) as well, which was found as the most common disorder (Dong et al., 2006).

Cherniack et al.'s (2010) research put dentists at the higher end of health care professionals in terms of musculoskeletal injury and lost work time.

Morse et al. (2010) provided that symptoms begin to appear early in the dentistry career, with significant increases upon starting clinical practice. They suggested that with the ergonomic improvements in the profession, the risk of musculoskeletal discomforts may have moved from the lower back to the upper extremities.

Disorders can affect body's muscles, tendons, joints, ligaments, and nerve system. Dentists may be forced to leave the job because disorders reduce work quality. The most common disorders' ranges are determined such as shoulder pain (21-81\%), neck pain (19.8-68\%). Interestingly, in 2003, only $19.8 \%$ Saudi Arabian dentists reported that they experience neck pain, whereas neck pain was reported by $67.9 \%$ of the dentists in 2008 (Lin et al., 2012).

Forward head posture was one of the reasons of neck pain among dentists who exceeded 15 years. It is clinically important to get rid of neck pain when the 
correct posture is found for head position. Some work related factors increase neck disorders such as prolonged static neck positions and repeated movements of neck which are demonstrated. For low back pain, symmetric body posture can cause disorders (Külcü et al., 2010).

The most common disorder was found as back pain followed by neck pain (Yousef and Al-Zain, 2009). The most common disorder is found low back pain for Danish and Australian dentists. Major risk factors such as repetitive movements, awkward and non-ergonomic positions, and forceful tasks can cause the disorders (Alexandre et al., 2011). Painful areas among dental works were revealed as lower back, upper back, hand/wrists, neck and/or shoulder and lower extremities (Kar and Mullick, 2012).

Dentists suffered musculoskeletal disorders with high rates (\%64) in Australia, Queensland is reported musculoskeletal disorders with high frequency in the past 12 months (\%87) also Thailand (\%78) (Hayes et al., 2013). The most common disorder was back pain (\%64) and wrist pain (\%69) in Sweden (Åkesson et al., 1999) and USA According to these results, training programs are existed in Australia for dental hygienists (Hayes et al., 2013).

According to examination amongst dentist, \%57 disorders are diagnosed which are including the trapezius muscles which are; tension neck syndrome (\%33), trapezius myalgia (\%22), and cervical syndrome (\%2). Also diagnosed is seen in shoulder region such as: acromioclavicular syndrome (\%14), shoulder tendonitis (\%8). In wrist and lower arm region \%16 disorders are diagnosed. Carpal syndrome (\%10 and \%6 bilaterally) and also overuse (\%5) are diagnosed (Åkesson et al., 2012).

Narrow visual field of oral cavity and working with a limited scope of movement can cause disorder in low back, neck, and wrist region among dentists. Disorders are still found after evaluation of seat and 4 handed dentistry (Rabiei et al., 2012).

Thanathornwong et al., (2012) constructed a system which intends to predict and prevent work related musculoskeletal disorders (WMSDs) among dentist. They found strong evidence that gender, age, repetitive movements were associated with WMSDs.

Dental profession requires visual activity, lateral bending of the spine, flexion of the neck, and the shoulder and pronation of the forearms (Kar and Mullick, 2012). ${ }^{8}$ Early retirement may be related with musculoskeletal disorders because almost 2 out of 3 dental professionals have experience work related pain (Madaan and Chaudhari, 2012).

Patel et al., (2012) found prevalence of low back pain, neck pain, and wrist pain among dentists. Zoidaki et al.,
(2013) found relationship between work and psychological risk factors and personnel characteristic among dentists.

Appropriate work area, suitable instruments, and correct posture are so important factors to reduce possible risk factors. Correct posture prevents some disorders that should be established early in the dental career while practicing. In the past, dentists considered patient's comfort however, nowadays, dentists have become aware of their occupational hazards as well.

This study will contribute to the literature by determining the risk factors of musculoskeletal discomforts among dentists, and identifying the impact of the dental tasks on the body regions during particular treatments.

\section{Methodology \\ 3.1. Questionnaire}

The questionnaire used in this study is uniquely prepared to investigate the disorders among dentists with the illustration of the external factors by the Borg Scale. Standardized Nordic Questionnaire (SNQ) was applied with acceptable questions which were answered by dentists to recognize symptoms in an ergonomic or occupational health context (Kuorinka et al., 1987). The survey questions were reviewed and approved by Eastern Mediterranean University Ethics Council in full accordance with the World Medical Association Declaration of Helsinki (reference number: ETK00-2015-0001, 06/01/2015). Written consents of the respondents were collected, which was approved by the ethics committee. Before distribution of questionnaire to dentists, a pilot study was conducted to confirm all questions' clarity for asking right questions and obtaining the correct answers.

Gender, age, height \& weight, years of practice, physical demands of dental practice, working time with patient (min), working hours per week, practice type, area of specialization, hand dominance, number of dental assistants, number of days worked per week, family situation, weekly exercise habits, taking break between patients, smoking \& alcohol habits, disorder occurrences in the past 12 months and past 7 days were collaborated in the questionnaire. Categorical questions included troubles (ache, pain, discomfort) in any body part, during the whole lifespan, during the last 12 months and during the last 7 days are also investigated in this questionnaire (Kuorinka et al., 1987).

Dentistry profession has such tasks which may lead to cause musculoskeletal disorders. Beyond the questions included in NMQ, previous syndromes and health in dentistry problems were also considered. Questionnaire has 22 multiple choice questions which ask the occurrence of disorders in neck, shoulders, upper back, 
wrists/hands, lower back, hip/tight, elbows and knees in past 12 months and the last 7 days among dentists.

The participants in this research were selected randomly from universities, hospitals, and dentists offices from Antalya, Turkey. The participants were the professionals who work on public or private dental clinics and in universities.

\subsection{Surface Electromyography (sEMG) Experiment}

Surface ElectroMyoGraphy (sEMG) is a non-invasive technique for measuring muscle electrical activity that occurs during muscle contraction and relaxation cycles. Surface electromyography is widely used in Ergonomics studies in the workplace, job risk analysis, product design and certification.

In this study, sEMG data were collected from dentists during patient treatment in order to understand which activities and posture are related to the musculoskeletal discomfort that the dentist experience. MyoTrac Infiniti, model SA9800 was used to collect muscle activities in this research. This sEMG device has two channels, which enable to collect data from two different muscle groups at the same time. All signals were A/D converted at 512 $\mathrm{Hz}$ which were then transmitted and then we can obtain the data for analyzing the statistical method.

Six muscle groups were selected for muscle activity investigation. These are; hand/wrist (flexor retinaculum), elbow/forearm (flexor carpi radialis), neck (posterior upper trapezius), shoulder (posterior deltoid), upper back (rhomboideus major), and lower back (sacropinalis).

SEMG experiment was conducted on randomly selected 3 dentists, who participated in the questionnaire. In order to collect data from all six muscle groups, the experiment was repeated three times (the device has two channels). They were examined to identify muscle activity for each task which they performed. However, one condition which must be taken into account was the patient privacy. Permission was required to take photos and video captures of the patient while the dentists were operating.

All measurements were obtained from the dental clinics with similar working conditions. Each examined dentist had no assistant whilst treating patients. It was also observed that their instruments were different. Dentists have been using different adjustments based on their job tasks and patients. Moreover, environmental factors such as lighting, ventilation, and temperature were kept at a normal level while taking data from dentists. The clinic's environment is kept in an optimal range with the following parameters; Artificial illumination of 10,000 lux, the room temperature of $20-25^{\circ} \mathrm{C}$ and $20 \%-60 \%$ of humidity.
Figure 1-3 show the sEMG study applied to the dentists while treating patients. Due to the patients' rights and preferences of dentists, it was not possible to take photo from operation. The exact positions of electrodes are shown within circles. With the permission of some patients, the following figures give a better understanding of how the sEMG study was done.

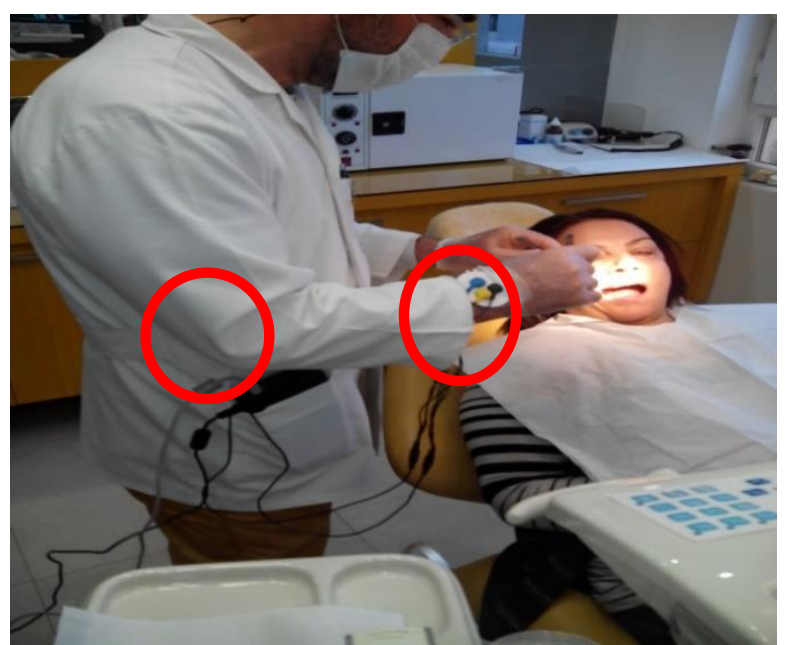

Figure 1. Placement of sEMG electrodes on hand/wrist (musculi lumbricales manus) and forearm (extensor carpi radialis)

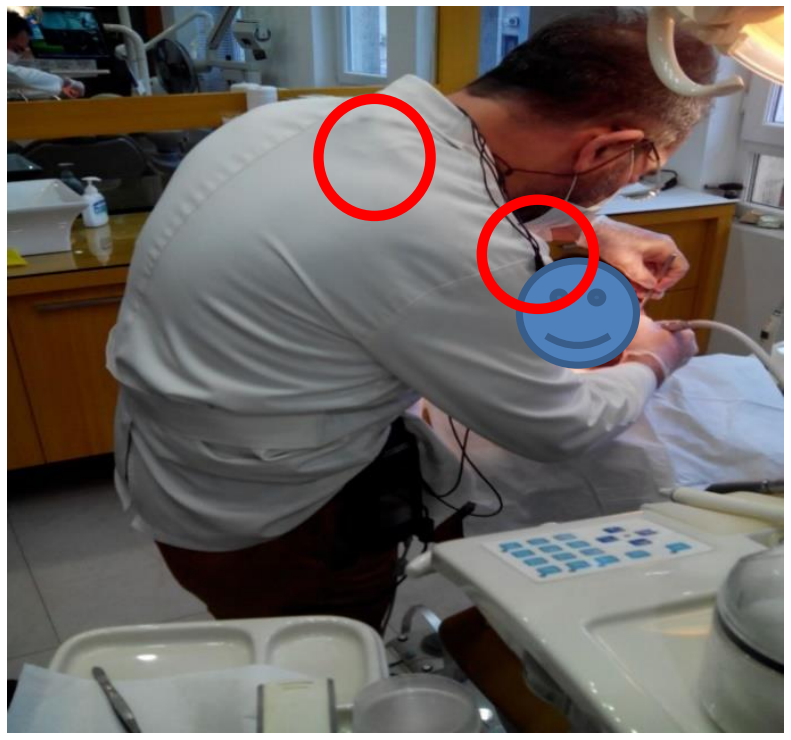

Figure 2. Placement of sEMG electrodes on shoulder (posterior deltoid) and neck (posterior upper trapezius) 


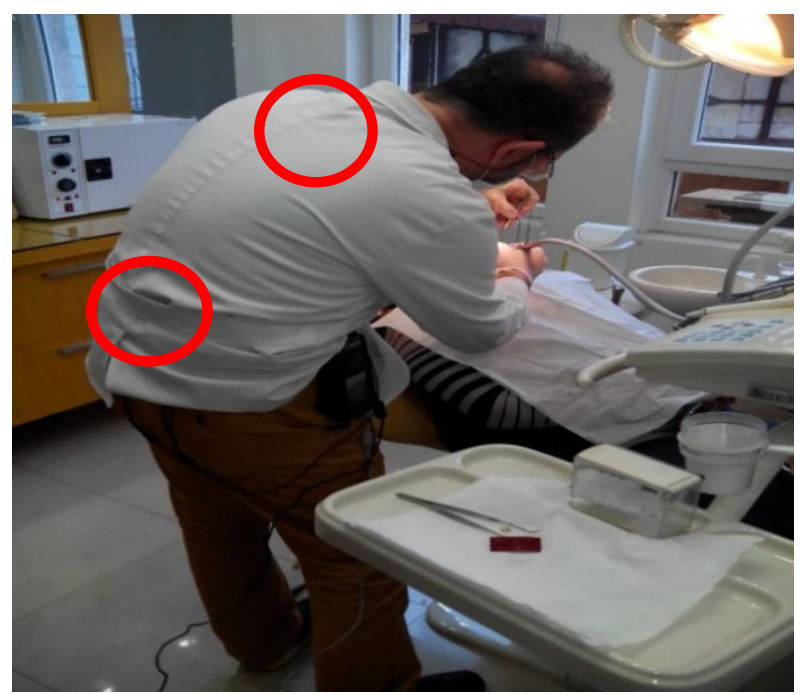

Figure 3. Placement of sEMG electrodes on upper back (posterior upper trapezius) and lower back (sacropinalis)

\subsection{Data Analysis}

In this research, collected data were included grouping variables and predictor variables. Due to this reason Discriminant Analysis was applied to determine whether a set of variables is effective in predicting category membership, and to identify statistically significant factor(s) which contribute(s) formation of the WRMSDs.

ANOVA analysis was also used to analyze the results which were obtained from sEMG experiment and to determine the risk factors of work related musculoskeletal disorders.

\subsection{Research Hypotheses}

There are two hypotheses are to be tested in this research. The first hypothesis is that:

$H_{0}=$ The median frequency (MDF) electrical activity [in time] in the six muscle group does not differ

The following shows the parameters of the second hypothesis to be tested in this research:

$i$ : the number of muscle regions. $\{i$ : $1=$ hand/wrist, $2=$ forearm, $3=$ neck, $4=$ shoulder, $5=$ upper back, $6=$ lower back\}

$j$ : the number of job tasks applied by dentists in 10 minutes. $\{j: 1=$ dental filling therapy, $2=$ tooth cleaning, $3=$ fixed prosthodontics, $4=$ tooth extraction, 5= endodontic, $6=$ dental examination, $7=$ removable prosthodontics \} $z$ : the number of dentists. $\{z: 1,2,3\}$

$\mu_{i j z}$ : The median frequency (MDF) electrical activity in the muscle i, for job j, by dentists $\mathrm{z}$.

$H_{0}: \mu_{i j z}=\mu_{i j z}$

$H_{1}: \mu_{i j z} \neq \mu_{i j z}$

In the hypothesis, each dentist was identified by the $z$ value. When the dentist was performing a task which was defined by $j^{\text {th }}$ parameter, the corresponding muscle group was taken into account. The muscle group was defined by $i^{\text {th }}$ parameter. This leads to obtain the MDF of the certain dentist related to his/her corresponding task and muscle region.

For instance, when a dentist is performing task $j$, the corresponding activity in muscle group of $i$ is measured by using the sEMG device. When the same dentist performs other task, again the same group of muscles is measured. By using this hypothesis, we are able to obtain the workload pressure on the muscle groups and come up with suggestions in order to decrease the workload for each task.

\section{Results}

\subsection{Questionnaire Results}

Out of 67 dentists, 42 (64.62\%) of them were male and 23 (35.38\%) were female (and 2 hops). Participants stated that 19 (58.79\%) of them were $41-50$ years old, $18(27.27 \%)$ of them were 51-60 years old, and 16 (24.24\%) were 31-40 years old. 24 respondents' $(35.82 \%)$ height was between $171-180 \mathrm{~cm}, 18$ (26.87\%) of them stated that their height was $181-190 \mathrm{~cm}$, and another group of $18(26.87 \%)$ respondents stated that their height were 161-170 cm. Moreover, 17 (25.37\%) of the respondents' weight was between $71-80 \mathrm{~kg}, 14$ $(20.90 \%)$ stated that they were $81-90 \mathrm{~kg}, 13(19.40 \%)$ mentioned that they were $61-70 \mathrm{~kg}$, and 12 (20.90\%) provided that that they were $91-100 \mathrm{~kg}$.

The majority (19 respondents, $28.36 \%$ ) of the dentists were in the profession for 21-30 years, and two groups $16(23.88 \%)$ respondents stated that they have been working for 11-20 years, and 31-40 years, and 13 $(19.40 \%)$ stated that they have been practicing for 1-10 years.

Figure 4 illustrates that prolonged standing and sitting positions were the most common physical demand of dental practice for $58(86.57 \%)$ dentists. This was followed by monotonous/repetitive movements $(74.63 \%)$ and hand force (62.69\%), respectively. 


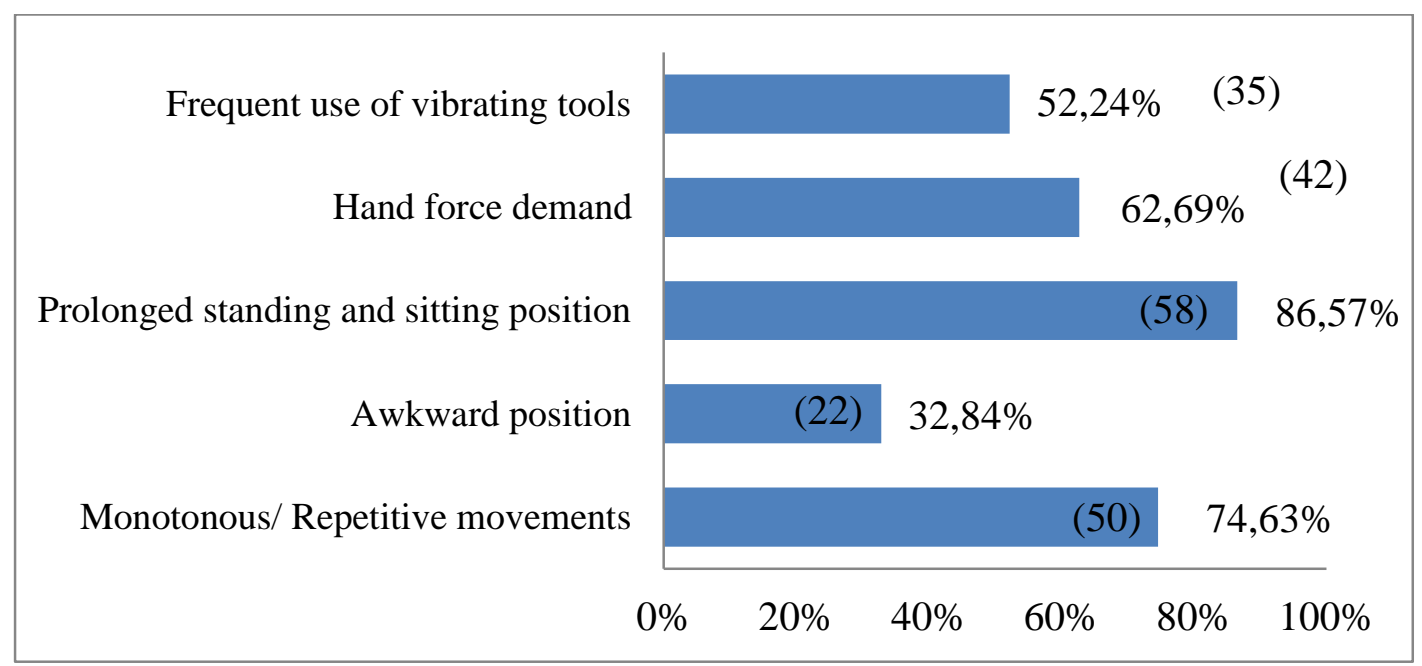

Figure 4: Physical demands of dental practice distribution of the respondents $(n=67)$

Two groups of $23(34.85 \%)$ dentists treat the patients for $21-30$ and $31-40$ minutes durations. 8 (12.12\%) dentists were spending 41-50 minutes for treating their patients. Another two groups of $6(9.09 \%)$ dentists treat their patients for 11-20 and for more than 50 minutes.

31-40 hours weekly was the most preferred working schedule by 29 (43.28\%) dentist's responses. 41-50 hours and more than 50 hours were selected by 12 $(17.91 \%)$ dentists.

In this research, 66 (98.51\%) of dentists were using the right hand, and only one (1.49\%) dentist was left handed.

No assistant was required for $16(23.88 \%)$ dentists. However, 47 (70.15\%) dentists were working together with an assistant and $4(5.97 \%)$ dentists have been working together with $2-5$ assistants.

Questionnaire statistics revealed that 26 (29.39\%) of the dentists were working for 7 days a week, 15 (22.73\%) were working for 6 days a week, $10(15.15 \%)$ were working for 5 days a week. The rest of the participants stated that they were working for less than 4 days a week.

When the life conditions of the dentists were considered, 57 (91.94\%) of them were living with the relatives or friends. The rest $5(8.06 \%)$ dentists stated that they were living alone.

Weekly exercise habits of the dentists revealed that more than half of dentists (53.76\%) did not do exercise at all and $12(17.91 \%)$ dentists exercised once a week. 8 (11.94\%) have emerged as the number of dentists who exercised twice per week. $6(8.96 \%)$ participants exercised 3 times in a week and $3(4.48 \%)$ dentists also exercised 4 times in a week. The rest 2 dentists regularly exercised 5 and 7 times in a week, respectively.

Moreover, 27 (40.30\%) dentists continued operating without any breaks and 40 (59.70\%) dentists gave a break between treatments. Only 10 dentists $(14.93 \%)$ smoking and the rest did not smoke. Also, 18 (27.27\%) dentists drank alcohol in daily life, while 48 (72.73\%) of them did not (hop: 1).

Stress levels in the environment are shown in the Figure 5 based on assessment scale. Most dentists stated as 5 out of 10 stress levels as indicated on the scale $(0=$ No stress, $10=$ unbearable stress). 


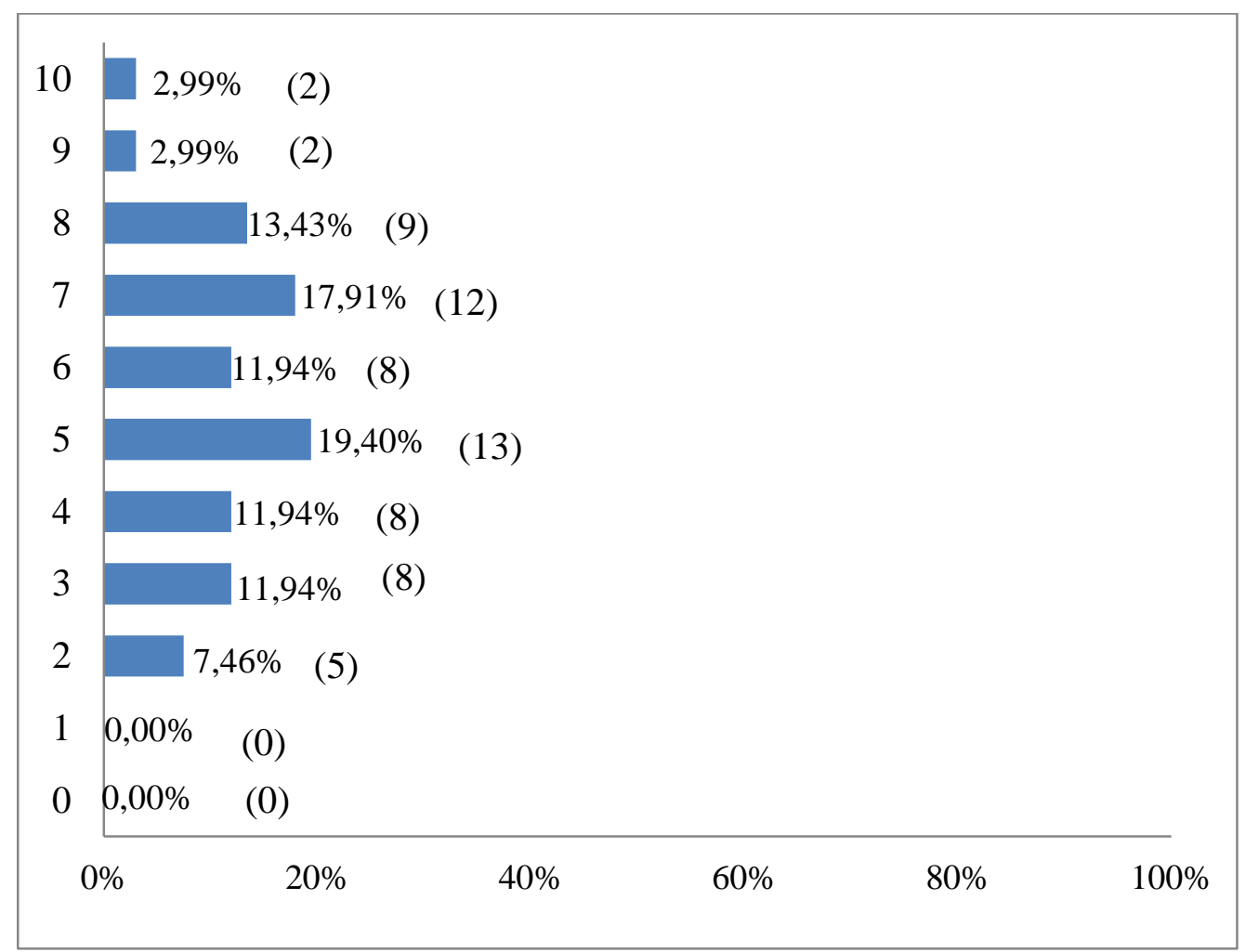

Figure 5: Distribution of stress level in their environment among respondents ( $n=67)$

Physical demand of hobbies were considered on scale as shown in Figure $6(0=$ none, $10=$ very high $)$. The most stated level was 5 by $10(15.15 \%)$ dentists based on their physical demand of hobbies.

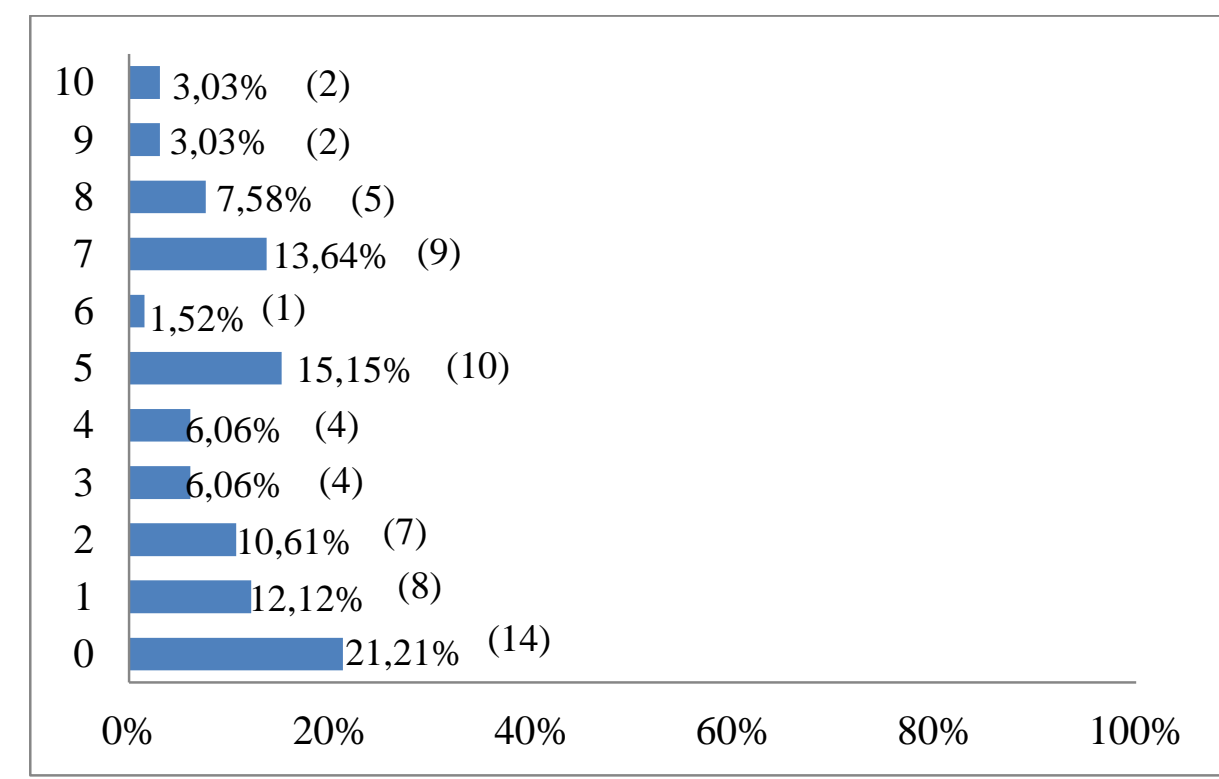

Figure 6: Distribution of physical demand of their hobbies among respondents $(n=66$, hops=1)

Questionnaire results (Figure 7) also showed that the most performed typical work tasks was dental filling therapy $(74.63 \%)$, followed by tooth cleaning $(52.24 \%)$, fixed prosthodontics (52.24\%), tooth extraction
$(47.76 \%)$, endodontic treatment $(46.27 \%)$, dental examination (44.78\%), and removable prosthodontics (35.82\%). 


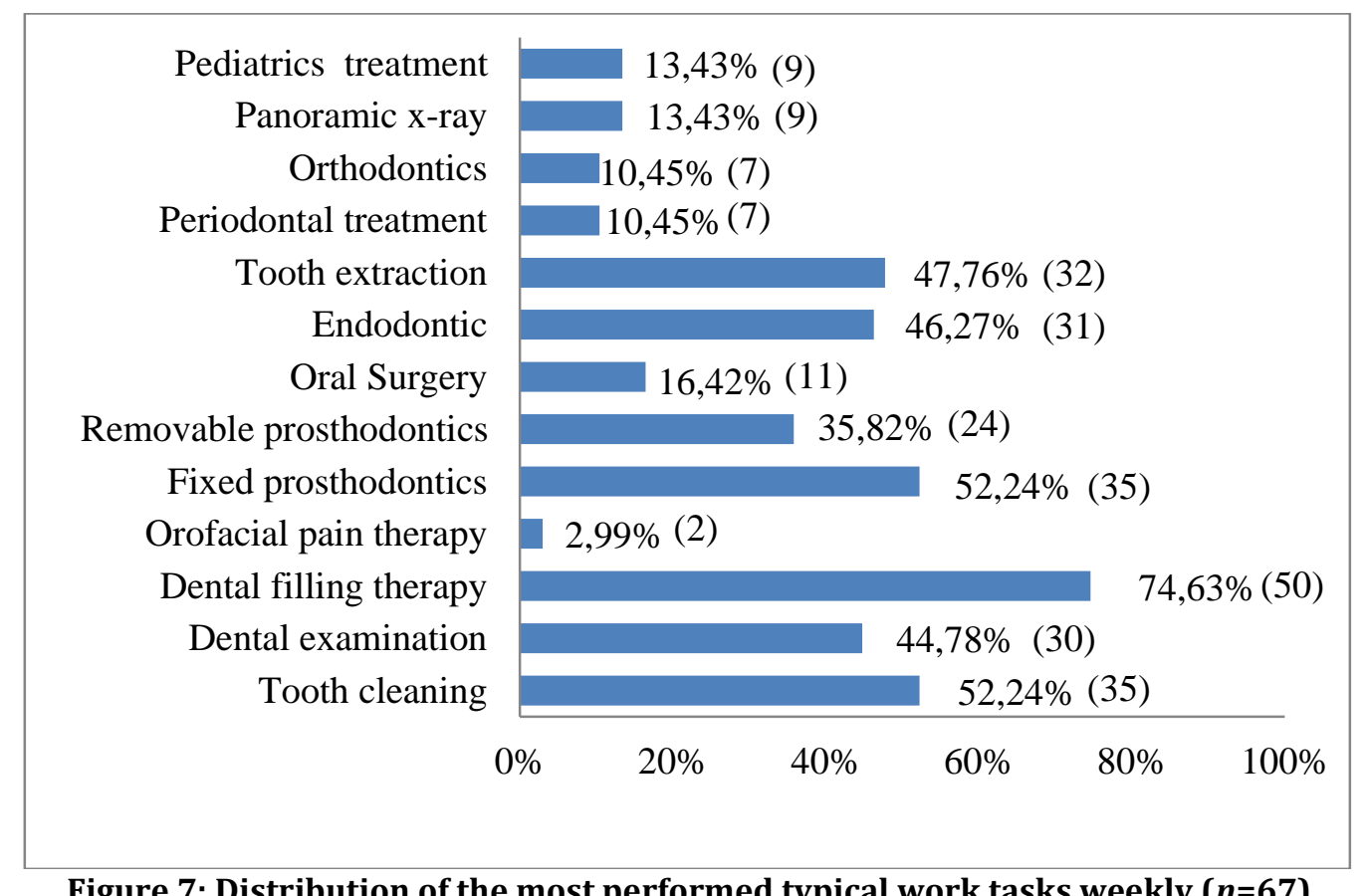

Figure 7: Distribution of the most performed typical work tasks weekly $(n=67)$

Table 1 shows the distribution of the discomfort occurrence in the past 12 months. It was revealed the chronic complaints at the shoulders (68.75\%), neck
(64.29\%), and upper back (61.11\%) are the highest perceived discomforts. Moreover, the most complaints collected from the dentists were resulted from the discomforts at the neck region (42 responses).

Table 1. Distribution of discomforts in the past 12 months $(n=64$, hops $=3)$

\begin{tabular}{lccccc}
\hline & $\begin{array}{c}\text { Chronic } \\
\text { complaints }\end{array}$ & $\begin{array}{c}\text { Complaints with } \\
\text { sickness absence }\end{array}$ & $\begin{array}{c}\text { Medical care } \\
\text { seeking }\end{array}$ & $\begin{array}{c}\text { Symptoms } \\
\text { preventing } \\
\text { normal activities }\end{array}$ & $\begin{array}{c}\text { Total } \\
\text { Responded }\end{array}$ \\
\hline Neck & $64.29 \%$ & $35.71 \%$ & $14.29 \%$ & $9.52 \%$ & 42 \\
Shoulders & 27 & 15 & 6 & 4 & 32 \\
Upper back & $68.75 \%$ & $31.25 \%$ & $15.63 \%$ & $15.63 \%$ & 36 \\
Lower back & 22 & 10 & 5 & 5 & 26 \\
Wrist /Hand & $61.11 \%$ & $36.11 \%$ & $8.33 \%$ & $8.33 \%$ & 39 \\
Hip/Thigh & 22 & 13 & 3 & 3 & 13 \\
& $53.85 \%$ & $42.31 \%$ & $30.77 \%$ & $26.92 \%$ & 7 \\
Ankles/Feet & 14 & 11 & 8 & $17.95 \%$ & 7 \\
Elbow & $46.15 \%$ & $46.15 \%$ & $20.51 \%$ & $7.69 \%$ & 24 \\
Knees & 18 & 18 & 8 & 1 & 13 \\
\hline
\end{tabular}

When the discomfort occurrence in the last 7 days is considered (Table 2), it is seen that the chronic complaints at the shoulders and the lower back are the highest (67.67\%), followed by chronic complaints at the neck $(63.16 \%)$. Unlikely to the past 12 months, data revealed from discomforts experienced in the past 7 days showed that upper back (24 responses) was the region where the most complaints aroused. 
Table 2. Distribution of discomforts in the past 7 days $(n=47$, hops $=20)$

\begin{tabular}{|c|c|c|c|c|c|}
\hline & $\begin{array}{l}\text { Chronic } \\
\text { complaints }\end{array}$ & $\begin{array}{l}\text { Complaints with } \\
\text { sickness absence }\end{array}$ & $\begin{array}{l}\text { Medical care } \\
\text { seeking }\end{array}$ & $\begin{array}{c}\text { Symptoms } \\
\text { preventing } \\
\text { normal activities }\end{array}$ & $\begin{array}{c}\text { Total } \\
\text { Responded }\end{array}$ \\
\hline \multirow{2}{*}{ Neck } & $63.16 \%$ & $31.58 \%$ & $5.26 \%$ & $10.53 \%$ & \multirow{2}{*}{19} \\
\hline & 12 & 6 & 1 & 2 & \\
\hline \multirow{2}{*}{ Shoulders } & $66.67 \%$ & $22.22 \%$ & $11.11 \%$ & $11.11 \%$ & \multirow{2}{*}{18} \\
\hline & 12 & 4 & 2 & 2 & \\
\hline \multirow{2}{*}{ Upper back } & $41.67 \%$ & $58.33 \%$ & $8.33 \%$ & $8.33 \%$ & \multirow{2}{*}{24} \\
\hline & 10 & 14 & 2 & 2 & \\
\hline \multirow{2}{*}{ Lower back } & $66.67 \%$ & $46.67 \%$ & $13.33 \%$ & $20.00 \%$ & \multirow{2}{*}{15} \\
\hline & 10 & 7 & 2 & 3 & \\
\hline \multirow{2}{*}{ Wrist/Hand } & $37.50 \%$ & $43.75 \%$ & $6.25 \%$ & $31.25 \%$ & \multirow{2}{*}{16} \\
\hline & 6 & 7 & 1 & 5 & \\
\hline \multirow{2}{*}{ Hip/Thigh } & $60.00 \%$ & $40.00 \%$ & $30.00 \%$ & $10.00 \%$ & \multirow{2}{*}{10} \\
\hline & 6 & 4 & 3 & 1 & \\
\hline \multirow{2}{*}{ Ankles/Feet } & $66.67 \%$ & $41.67 \%$ & $16.67 \%$ & $8.33 \%$ & \multirow{2}{*}{12} \\
\hline & 8 & 5 & 2 & 1 & \\
\hline \multirow{2}{*}{ Elbow } & $14.29 \%$ & $85.71 \%$ & $14.29 \%$ & $0.00 \%$ & \multirow{2}{*}{7} \\
\hline & 1 & 6 & 1 & 0 & \\
\hline \multirow{2}{*}{ Knees } & $53.85 \%$ & $38.46 \%$ & $0.00 \%$ & $7.69 \%$ & \multirow{2}{*}{13} \\
\hline & 7 & 5 & 0 & 1 & \\
\hline
\end{tabular}

\subsection{Discriminant Analysis}

The discriminant analysis was used to reveal significant relationship between work-related musculoskeletal discomforts and dentists. The dependent variables are selected to be the discomforts in the past 7 days and past 12 months, respectively. Also, the independent variables were selected from rest of the questionnaire questions. The first analysis was constructed to determine the significant factors for the discomforts in the last 12 months for neck, shoulder, wrist/hand, upper back, lower back, knees, ankles/feet, hip/thigh, and elbow regions. A latter analysis was constructed to determine the significant factors for the discomforts experienced in the past 7 days. Discriminant analysis has been sustained by using SPSS 19 software.

Table 3 compares the significant factors for wrists/hand region in the past 12 months and past 7 days. The only common significant factors at the wrist/hand region were observed as the "physical demands of dental practice" in each time interval. 
Eskişehir Osmangazi Üniversitesi Mühendislik ve Mimarlık Fakültesi Dergisi 26(2), 47-67, 2018

Table 3: Discriminant function coefficients for wrists/hand

\begin{tabular}{|c|c|c|c|c|c|c|c|c|}
\hline \multirow{2}{*}{\multicolumn{3}{|c|}{ Past 12 months }} & \multicolumn{3}{|c|}{ Function } & \multirow{2}{*}{\multicolumn{2}{|c|}{ Past 7 days }} & \multirow{2}{*}{$\begin{array}{c}\text { Function } \\
1 \\
\end{array}$} \\
\hline & & & 1 & 2 & 3 & & & \\
\hline $\begin{array}{l}\text { Physical } \\
\text { Practice }\end{array}$ & Demands of & Dental & 20.486 & 2.583 & .032 & Gender & & 15.040 \\
\hline \multicolumn{3}{|c|}{ Work Tasks } & -8.217 & 2.660 & .244 & Age (year) & & 28.070 \\
\hline \multicolumn{3}{|c|}{ Physical demand of hobbies } & 19.433 & 5.319 & .342 & Height $(\mathrm{cm})$ & & 11.019 \\
\hline \multicolumn{3}{|l|}{ Alcohol } & 7.641 & .545 & .947 & Weight (kg) & & 1.891 \\
\hline \multicolumn{3}{|c|}{ Stress level } & 5.864 & .526 & .273 & Practice years & & -15.744 \\
\hline \multicolumn{3}{|c|}{ Weekly exercise habit } & .171 & -2.750 & -.401 & $\begin{array}{l}\text { Physical Demands of } \\
\text { Practice }\end{array}$ & Dental & .896 \\
\hline \multicolumn{3}{|c|}{ Take break between patients } & -24.977 & 9.766 & -.373 & $\begin{array}{l}\text { Working time with } \\
\text { (min) }\end{array}$ & patient & 3.054 \\
\hline \multirow{3}{*}{\multicolumn{3}{|c|}{ Days worked per week }} & 7.722 & -7.201 & -.402 & \multicolumn{2}{|l|}{ Working hours per week } & 5.388 \\
\hline & & & & & & \multicolumn{2}{|l|}{ Area of Specialization } & 3.902 \\
\hline & & & & & & \multicolumn{2}{|l|}{ Dental Assistant Usage } & 4.087 \\
\hline
\end{tabular}

Table 4 illustrates the significant factors to contribute musculoskeletal discomfort at the shoulder region during the past 12 months and the past 7 days. It is observed that in both periods, there is no common significant factor.

Table 4: Discriminant function coefficients for shoulder

\begin{tabular}{|c|c|c|c|c|c|c|c|c|}
\hline \multirow{2}{*}{ Past 12 months } & \multicolumn{4}{|c|}{ Function } & \multirow{2}{*}{ Past 7 days } & \multicolumn{3}{|c|}{ Function } \\
\hline & 1 & 2 & 3 & 4 & & 1 & 2 & 3 \\
\hline $\begin{array}{l}\text { Physical Demands of } \\
\text { Dental Practice }\end{array}$ & 8.012 & .361 & .648 & .503 & Gender & 2.243 & 2.641 & .958 \\
\hline Work Tasks & 2.951 & .608 & .599 & 1.012 & Age (year) & -1.289 & 2.097 & 1.638 \\
\hline $\begin{array}{l}\text { Physical demand of } \\
\text { hobbies }\end{array}$ & 4.721 & .097 & .788 & .698 & Height $(\mathrm{cm})$ & -.602 & .130 & .637 \\
\hline Alcohol & 1.965 & .222 & .497 & .281 & Weight (kg) & .671 & .919 & .102 \\
\hline Stress level & -4.945 & .812 & -.580 & -.252 & Practice years & 2.763 & .316 & -1.694 \\
\hline Weekly exercise habit & -2.846 & .724 & .598 & -.327 & $\begin{array}{l}\text { Physical Demands of } \\
\text { Dental Practice }\end{array}$ & 2.580 & -.457 & .097 \\
\hline $\begin{array}{l}\text { Take break between } \\
\text { patients }\end{array}$ & -3.310 & -.430 & -1.207 & .136 & $\begin{array}{l}\text { Working time with } \\
\text { patient (min) }\end{array}$ & -2.490 & -.593 & .847 \\
\hline $\begin{array}{l}\text { Days worked per } \\
\text { week }\end{array}$ & 3.678 & .071 & .289 & -.758 & Area of Specialization & -2.158 & -.563 & .108 \\
\hline
\end{tabular}

Table 5 compares the significant factors for neck region in the past 12 months and past 7 days. It is observed that in both periods, there is no common significant factor. 
Eskişehir Osmangazi Üniversitesi Mühendislik ve Mimarlık Fakültesi Dergisi 26(2), 47-67, 2018

Table 5: Discriminant function coefficients for neck

\begin{tabular}{|c|c|c|c|c|c|}
\hline \multirow{2}{*}{ Past 12 months } & \multicolumn{3}{|c|}{ Function } & \multirow{2}{*}{ Past 7 days } & \multirow{2}{*}{$\begin{array}{c}\text { Function } \\
1 \\
\end{array}$} \\
\hline & 1 & 2 & 3 & & \\
\hline $\begin{array}{l}\text { Physical Demands of Dental } \\
\text { Practice }\end{array}$ & 5.142 & 3.366 & 2.127 & Gender & 15.040 \\
\hline Work Tasks & 3.868 & 1.762 & 1.615 & Age (year) & 28.070 \\
\hline Physical demand of hobbies & 7.945 & 2.262 & 3.293 & Height $(\mathrm{cm})$ & 11.019 \\
\hline Alcohol & -3.833 & .506 & -.870 & Weight (kg) & 1.891 \\
\hline Stress level & -.436 & -1.872 & -1.282 & Practice years & -15.744 \\
\hline Weekly exercise habit & -5.228 & -1.325 & -1.761 & Physical Demands of Dental Practice & .896 \\
\hline $\begin{array}{l}\text { Take break between } \\
\text { patients }\end{array}$ & -2.602 & -.798 & -1.327 & Working time with patient (min) & 3.054 \\
\hline Days worked per week & -.231 & .944 & -.125 & Working hours per week & 5.388 \\
\hline \multirow[t]{2}{*}{ Family Situation } & 8.193 & .129 & 2.461 & Area of Specialization & 3.902 \\
\hline & & & & Dental Assistant Usage & 4.087 \\
\hline
\end{tabular}

In table 6, the significant factors which contribute to musculoskeletal discomfort in the past 12 months and past 7 days are illustrated. Again, it is observed that there is no common significant factor for the both periods.

Table 6: Discriminant function coefficients for upper back

\begin{tabular}{|c|c|c|c|c|c|c|c|}
\hline \multirow{2}{*}{ Past 12 months } & \multicolumn{3}{|c|}{ Function } & \multirow{2}{*}{ Past 7 days } & \multicolumn{3}{|c|}{ Function } \\
\hline & 1 & 2 & 3 & & 1 & 2 & 3 \\
\hline $\begin{array}{l}\text { Physical Demands of } \\
\text { Dental Practice }\end{array}$ & -.570 & 7.370 & .852 & Gender & -.161 & 3.039 & 2.083 \\
\hline Work Tasks & .860 & 4.638 & .397 & Age (year) & 7.033 & -.703 & 2.496 \\
\hline $\begin{array}{l}\text { Physical demand of } \\
\text { hobbies }\end{array}$ & -1.524 & 9.366 & 1.245 & Height $(\mathrm{cm})$ & 2.428 & 1.086 & 1.490 \\
\hline Alcohol & 2.139 & -1.422 & -.245 & Weight (kg) & -1.519 & 2.525 & .159 \\
\hline Stress level & -3.042 & -3.527 & -1.078 & Practice years & -6.221 & 2.980 & -2.191 \\
\hline Weekly exercise habit & 5.915 & -5.665 & -.683 & $\begin{array}{l}\text { Physical Demands of } \\
\text { Dental Practice }\end{array}$ & .558 & -1.292 & .205 \\
\hline $\begin{array}{l}\text { Take break between } \\
\text { patients }\end{array}$ & 1.098 & -2.008 & -.749 & $\begin{array}{l}\text { Working time with } \\
\text { patient }(\mathrm{min})\end{array}$ & 4.482 & -1.381 & .596 \\
\hline Days worked per week & 4.477 & -.319 & -.234 & Working hours per week & .257 & -.757 & .880 \\
\hline Family Situation & -6.633 & 6.331 & .853 & & & & \\
\hline
\end{tabular}

Table 7 compares the significant factors for lower back region in the past 12 months and past 7 days. The only common significant factors at the lower back region were observed as the "physical demands of dental practice" in each time interval. 
Table 7: Discriminant function coefficients for lower back

\begin{tabular}{|c|c|c|c|c|c|c|c|c|}
\hline \multirow{2}{*}{ Past 12 months } & \multicolumn{3}{|c|}{ Function } & \multirow{2}{*}{ Past 7 days } & \multicolumn{4}{|c|}{ Function } \\
\hline & 1 & 2 & 3 & & 1 & 2 & 3 & 4 \\
\hline $\begin{array}{l}\text { Physical Demands of } \\
\text { Dental Practice }\end{array}$ & 9.729 & 5.198 & 1.849 & Gender & 18.412 & -1.121 & 1.044 & .607 \\
\hline Work Tasks & 4.641 & 1.959 & 1.549 & Age (year) & 2.324 & -3.310 & 1.138 & 1.716 \\
\hline $\begin{array}{l}\text { Physical demand of } \\
\text { hobbies }\end{array}$ & 9.926 & 3.845 & 3.901 & Height $(\mathrm{cm})$ & 14.392 & .838 & 1.137 & -.001 \\
\hline Alcohol & -3.935 & -3.749 & -2.055 & Weight (kg) & 11.484 & .179 & .223 & .702 \\
\hline Stress level & -4.674 & -3.984 & -1.167 & Practice years & 18.106 & 3.231 & -.655 & -1.200 \\
\hline $\begin{array}{l}\text { Weekly exercise } \\
\text { habit }\end{array}$ & -7.075 & -4.439 & -3.735 & $\begin{array}{l}\text { Physical Demands of } \\
\text { Dental Practice }\end{array}$ & -5.262 & 1.014 & .250 & .580 \\
\hline $\begin{array}{l}\text { Take break between } \\
\text { patients }\end{array}$ & -3.362 & -.218 & .436 & $\begin{array}{l}\text { Working time with } \\
\text { patient (min) }\end{array}$ & -2.912 & -.807 & .944 & -.353 \\
\hline $\begin{array}{l}\text { Days worked per } \\
\text { week }\end{array}$ & -1.067 & .488 & -.710 & & & & & \\
\hline Family Situation & 8.193 & 4.321 & 4.104 & & & & & \\
\hline
\end{tabular}

The significant factors which contribute to the musculoskeletal discomfort in the past 12 months and past 7 days are shown in table 8. It is once more observed that "physical demands of dental practice" is a common significant factor for the both time intervals.

Table 8: Discriminant function coefficients for knees

\begin{tabular}{|c|c|c|c|c|c|c|}
\hline \multirow{2}{*}{ Past 12 months } & \multicolumn{3}{|c|}{ Function } & \multirow{2}{*}{ Past 7 days } & \multirow[b]{2}{*}{1} & \multirow[b]{2}{*}{2} \\
\hline & 1 & 2 & 3 & & & \\
\hline Physical Demands of Dental Practice & 15.731 & -.999 & .113 & Gender & 19.115 & 2.379 \\
\hline Work Tasks & 4.834 & 1.309 & 1.172 & Age (year) & -8.680 & 10.112 \\
\hline Physical demand of hobbies & 4.475 & .615 & .186 & Height $(\mathrm{cm})$ & .091 & 1.122 \\
\hline Alcohol & 8.228 & 2.511 & .548 & Weight (kg) & 10.330 & -1.474 \\
\hline Stress level & -9.496 & 1.990 & -.685 & Practice years & 23.045 & -7.560 \\
\hline Weekly exercise habit & 3.118 & .089 & -.314 & $\begin{array}{l}\text { Physical Demands of } \\
\text { Dental Practice }\end{array}$ & 9.467 & -.148 \\
\hline Take break between patients & -10.390 & -1.152 & -.197 & $\begin{array}{l}\text { Working time with patient } \\
\text { (min) }\end{array}$ & -1.383 & 1.710 \\
\hline \multirow[t]{2}{*}{ Days worked per week } & 2.637 & -.543 & .729 & Working hours per week & -14.822 & 1.956 \\
\hline & & & & Area of Specialization & -5.402 & -1.592 \\
\hline
\end{tabular}

In table 9, the significant factors which contribute to the musculoskeletal discomfort in the past 12 months and 7 days are illustrated. "Physical demands of dental practice" is found to be a common significant factor for both durations. 
Eskişehir Osmangazi Üniversitesi Mühendislik ve Mimarlık Fakültesi Dergisi 26(2), 47-67, 2018

Table 9: Discriminant function coefficients for hip/thigh

\begin{tabular}{|c|c|c|c|c|c|c|}
\hline \multirow{2}{*}{ Past 12 months } & \multicolumn{2}{|c|}{ Function } & \multirow{2}{*}{ Past 7 days } & \multicolumn{3}{|c|}{ Function } \\
\hline & 1 & 2 & & 1 & 2 & 3 \\
\hline $\begin{array}{l}\text { Physical Demands of Dental } \\
\text { Practice }\end{array}$ & 3.477 & 1.868 & Gender & 9.027 & 1.218 & 2.274 \\
\hline Work Tasks & .014 & 1.182 & Age (year) & -22.872 & 13.407 & 2.002 \\
\hline Physical demand of hobbies & .337 & 2.731 & Height $(\mathrm{cm})$ & -.198 & 1.470 & 1.486 \\
\hline Alcohol & -.930 & .249 & Weight (kg) & 8.701 & -.180 & .301 \\
\hline Stress level & -3.705 & -.191 & Practice years & 27.941 & -10.680 & -.577 \\
\hline Weekly exercise habit & -.629 & -1.022 & $\begin{array}{l}\text { Physical Demands of Dental } \\
\text { Practice }\end{array}$ & 4.696 & .148 & -.631 \\
\hline Take break between patients & 1.072 & -1.815 & $\begin{array}{l}\text { Working time with patient } \\
\text { (min) }\end{array}$ & -4.086 & 2.987 & -.170 \\
\hline Days worked per week & 1.835 & -1.174 & Working hours per week & -12.505 & 3.227 & .262 \\
\hline Family Situation & .076 & 1.765 & & & & \\
\hline Dental Assistant Usage & 2.338 & -.867 & & & & \\
\hline
\end{tabular}

Table 10 illustrates the significant factors which contribute to the musculoskeletal discomfort in the past 12 months and past 7 days at the ankle/feet. One more time, "physical demands of dental practice" is observed to be a common significant factor for both time intervals.

Table 10: Discriminant function coefficients for ankle/feet

\begin{tabular}{lrrlrr}
\hline \multicolumn{1}{c}{ Past 12 months } & \multicolumn{2}{c}{ Function } & \multicolumn{2}{c}{ Past 7 days } & \multicolumn{2}{c}{ Function } \\
& \multicolumn{1}{c}{1} & \multicolumn{1}{c}{2} & \multicolumn{2}{c}{2} \\
\hline Physical Demands of Dental Practice & 6.966 & 1.365 & Gender & 19.115 & 2.379 \\
Work Tasks & 4.324 & .409 & Age (year) & -8.680 & 10.112 \\
Physical demand of hobbies & 4.974 & 2.114 & Height (cm) & .091 & 1.122 \\
Alcohol & -.759 & -.296 Weight (kg) & 10.330 & -1.474 \\
Stress level & -12.670 & -.171 & Practice years & 23.045 & -7.560 \\
Weekly exercise habit & .122 & -1.637 & Physical Demands of Dental Practice & 9.467 & -.148 \\
Take break between patients & 7.488 & .211 Working time with patient (min) & -1.383 & 1.710 \\
Days worked per week & 3.523 & -.596 Working hours per week & -14.822 & 1.956 \\
Family Situation & -.245 & 1.910 Area of Specialization & -5.402 & -1.592 \\
Dental Assistant Usage & 2.428 & .151 & & \\
\hline
\end{tabular}

For the elbow region, the significant factors which contribute to the musculoskeletal discomfort for the past 12 months and past 7 days are shown in table 11 . It was found that "physical demands of dental practice" and "dental assistant usage" are the common significant factors for the given time intervals. 
Table 11: Discriminant function coefficients for elbow

\begin{tabular}{|c|c|c|c|c|c|}
\hline \multirow{2}{*}{ Past 12 months } & \multicolumn{2}{|c|}{ Function } & \multirow{2}{*}{ Past 7 days } & \multirow[b]{2}{*}{1} & \multirow[b]{2}{*}{2} \\
\hline & 1 & 2 & & & \\
\hline $\begin{array}{l}\text { Physical Demands of Dental } \\
\text { Practice }\end{array}$ & .026 & -1.242 & Gender & 4.131 & 5.041 \\
\hline Work Tasks & .764 & .434 & Age (year) & 8.986 & 9.486 \\
\hline Physical demand of hobbies & .787 & -.844 & Height $(\mathrm{cm})$ & 2.627 & 2.946 \\
\hline Alcohol & -.110 & .160 & Weight (kg) & -2.258 & .069 \\
\hline Stress level & 1.775 & -.030 & Practice years & -6.034 & -5.209 \\
\hline Weekly exercise habit & -1.203 & .433 & $\begin{array}{l}\text { Physical Demands of Dental } \\
\text { Practice }\end{array}$ & 2.086 & .456 \\
\hline Take break between patients & -1.556 & 1.049 & Working time with patient (min) & 3.357 & 2.101 \\
\hline Days worked per week & -.991 & .519 & Working hours per week & .316 & 1.257 \\
\hline Family Situation & 1.473 & -.691 & Dental Assistant Usage & 5.058 & 1.690 \\
\hline Dental Assistant Usage & -.348 & .462 & & & \\
\hline
\end{tabular}

\section{3 sEMG Experiment Results}

Out of 13 common tasks among dentists, the most common 7 of them were chosen for investigation due to their highest percentages as the most common tasks (Figure 7). The 7 most tasks (those above 35\%) are listed as the following: Dental filling therapy, Tooth cleaning, Fixed prosthodontics, Tooth extraction, Endodontic, Dental examination, and Removable prosthodontics.

Figure 8 illustrates that fixed prosthodontics requires highest muscular effort but reduces in time at the hand of dentist 1 . Whereas, tooth cleaning and dental examination are the highly demanding treatments for the dentists 2 . Similarly dentist 2 , hand muscle activities during dental examination was observed to be increasing for the dentist 3.

Dental examination was observed to demand high level muscular activity at the elbows of the all 3 dentists (figure 9). Moreover, endodontic treatment and removable prosthodontic were observed to be highly muscular demanding treatments for the dentist 2 and dentist 3 , respectively. 
Eskişehir Osmangazi Üniversitesi Mühendislik ve Mimarlık Fakültesi Dergisi 26(2), 47-67, 2018
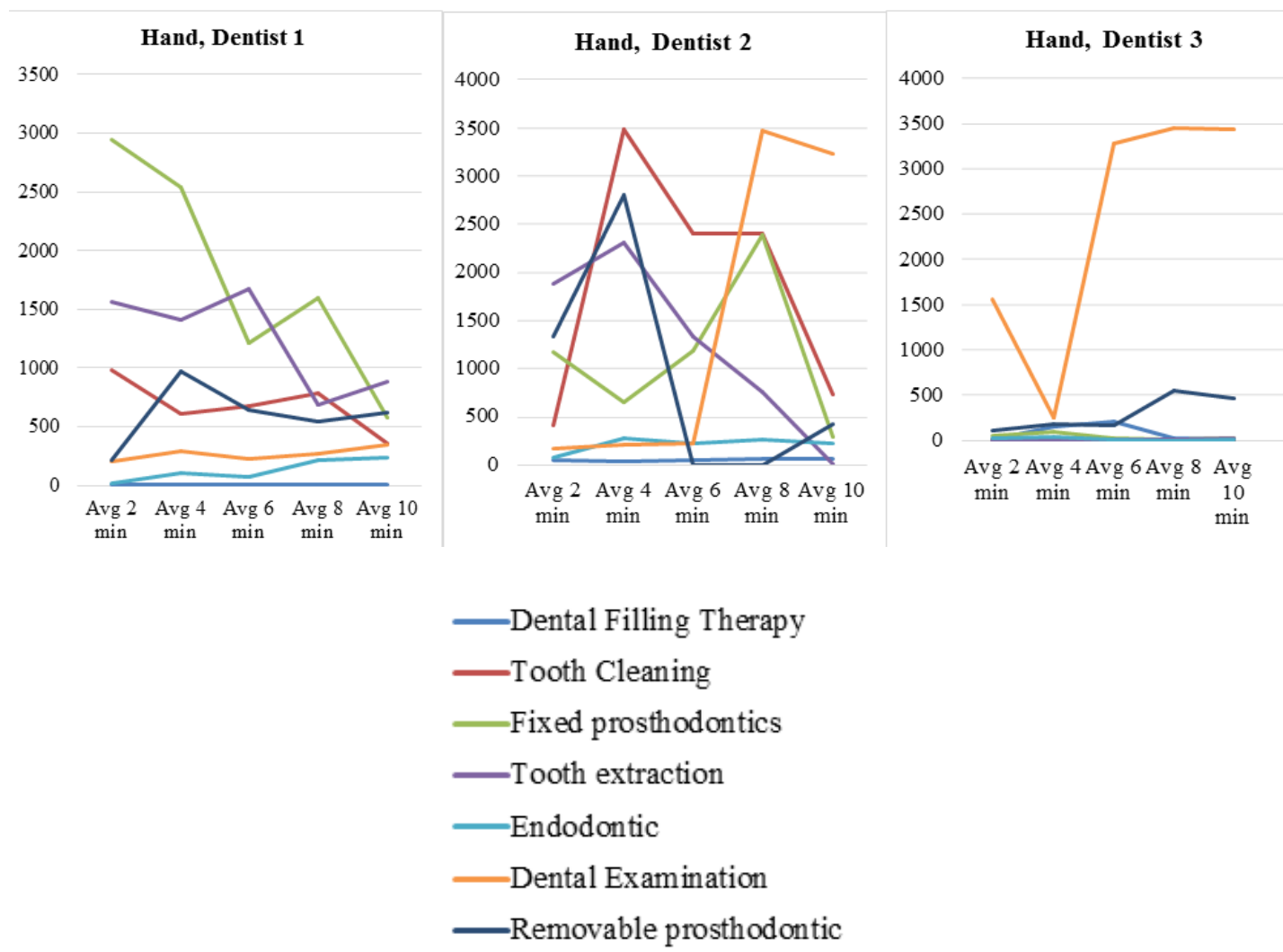

Figure 8: Muscular activities (in $\mu \mathrm{V}$ ) of the 3 dentists at their hand (flexor retinaculum) during most common 7 treatments
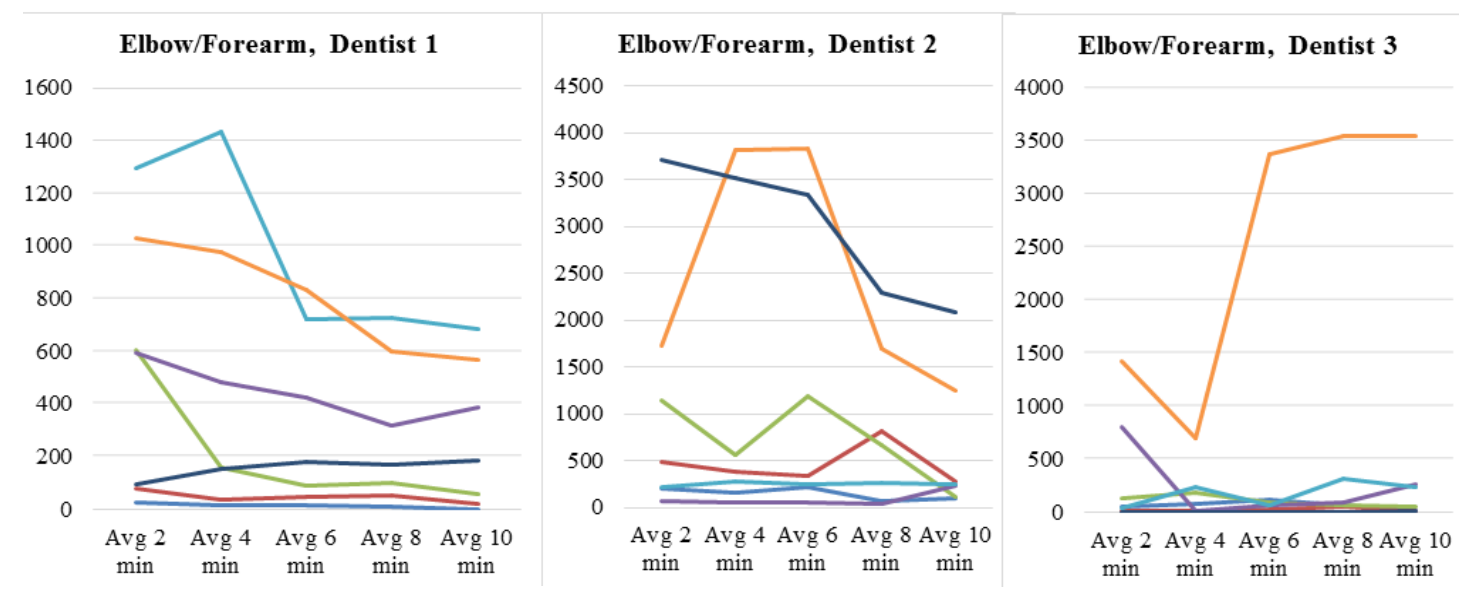

-Dental Filling Therapy

-Tooth Cleaning

-Fixed prosthodontics

-Tooth extraction

Endodontic

-Dental Examination

-Removable prosthodontic

Figure 9: Muscular activities (in $\mu \mathrm{V}$ ) of the 3 dentists at their elbow/forearm (flexor carpi radialis) during most common 7 treatments 
Figure 10 shows that endodontic treatment requires high level of muscular activity at the neck of the dentist 1 and dentist, where it reduces in time for dentist 1. Moreover, dentist 1 was observed to experience high level of neck muscle activities during fixed prosthodontic and removable prosthodontic treatments. In addition, the dentist 2 was observed to experience various levels of neck muscle activities from the treatments except removable prosthodontic.

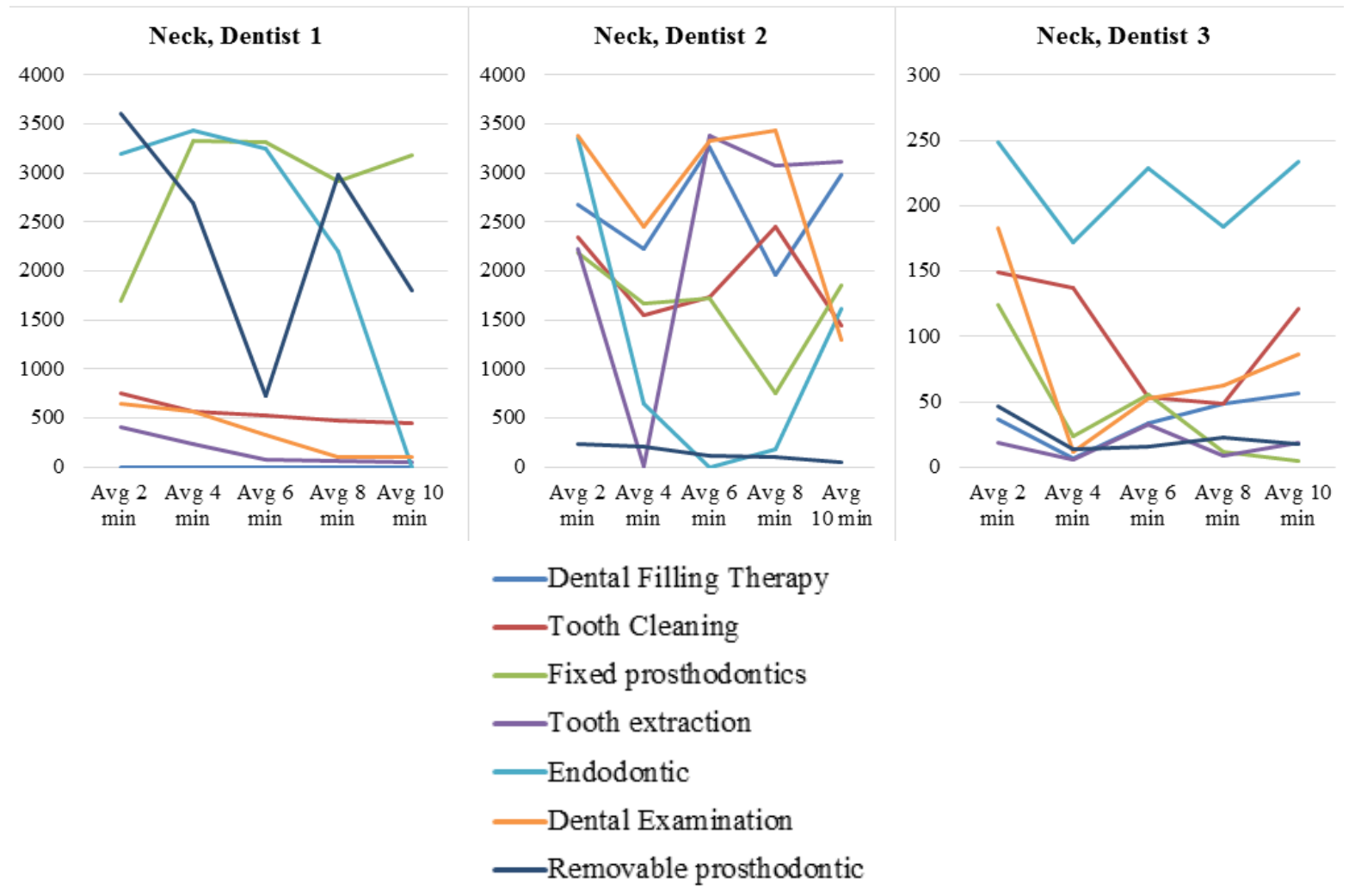

Figure 10: Muscular activities (in $\mu \mathrm{V}$ ) of the 3 dentists at their neck (posterior upper trapezius) during most common 7 treatments

It was observed that the dentist 1 experienced highest muscular demand at the shoulder during dental examination. It was also observed that, the shoulder muscle activities were decreasing during removable prosthodontic while the increasing for the endodontic treatment in time. The dentist 2 was observed to suffer from high levels of muscular activities at the shoulder during all treatments. Fixed prosthodontics treatment was observed to reflect increasing muscular activity at the shoulder in time for the dentist 3 (figure 11).
Figure 12 illustrates that the dentist 1 and 2 demands high level muscular activity at the upper back during removable prosthodontic treatment (12). Moreover, the dentist 1 demanded high level muscle use during endodontic and tooth extraction treatments. Dental filling therapy demanded the dentist 2 to use upper back muscles most during the treatment. Also, the dentist 3 was observed to experience reducing muscular effort at the upper back during fixed prosthodontics treatment. 
Eskişehir Osmangazi Üniversitesi Mühendislik ve Mimarlık Fakültesi Dergisi 26(2), 47-67, 2018
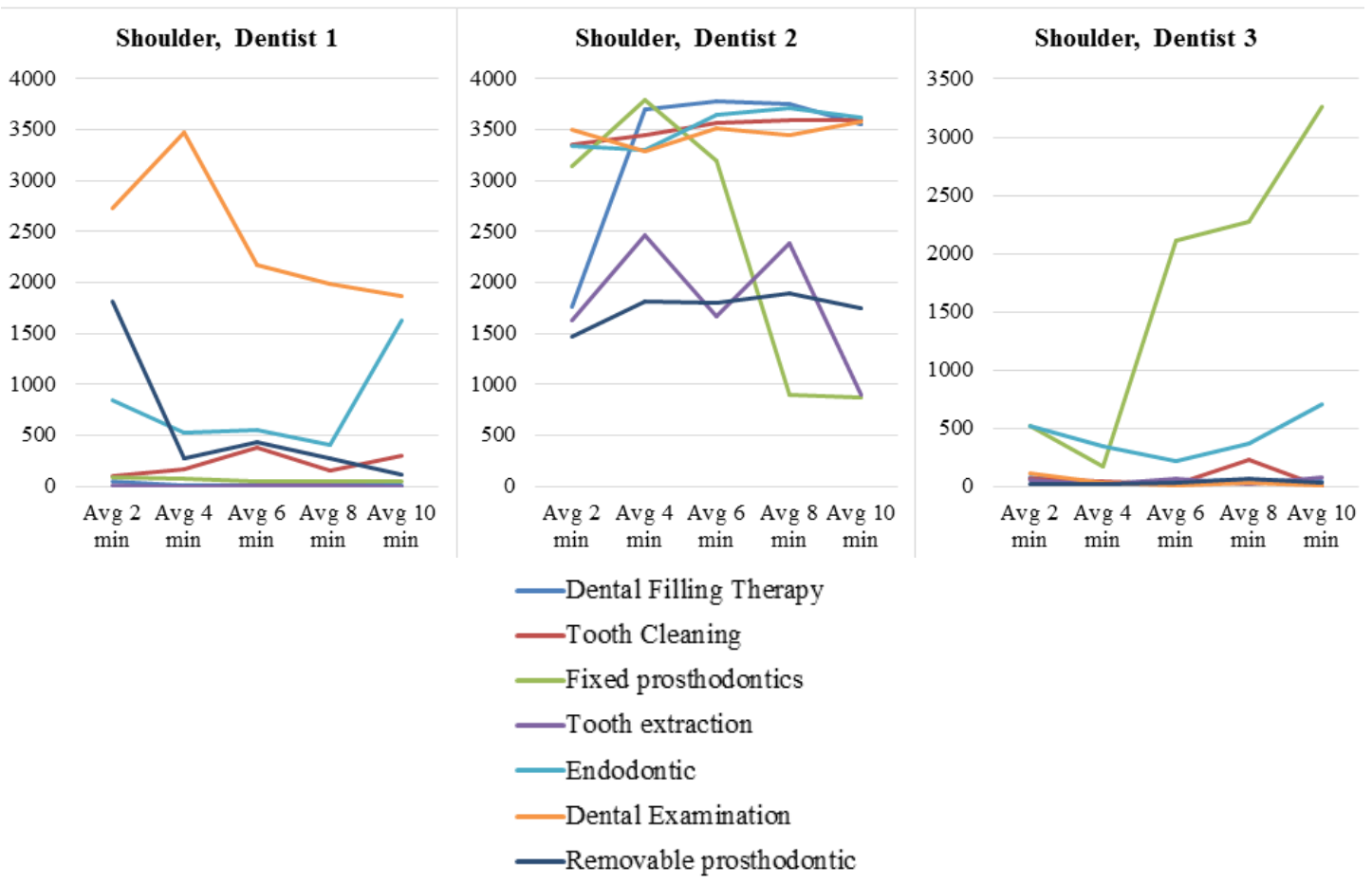

Figure 11: Muscular activities (in $\mu \mathrm{V}$ ) of the 3 dentists at their shoulder (posterior deltoid) during most common 7 treatments
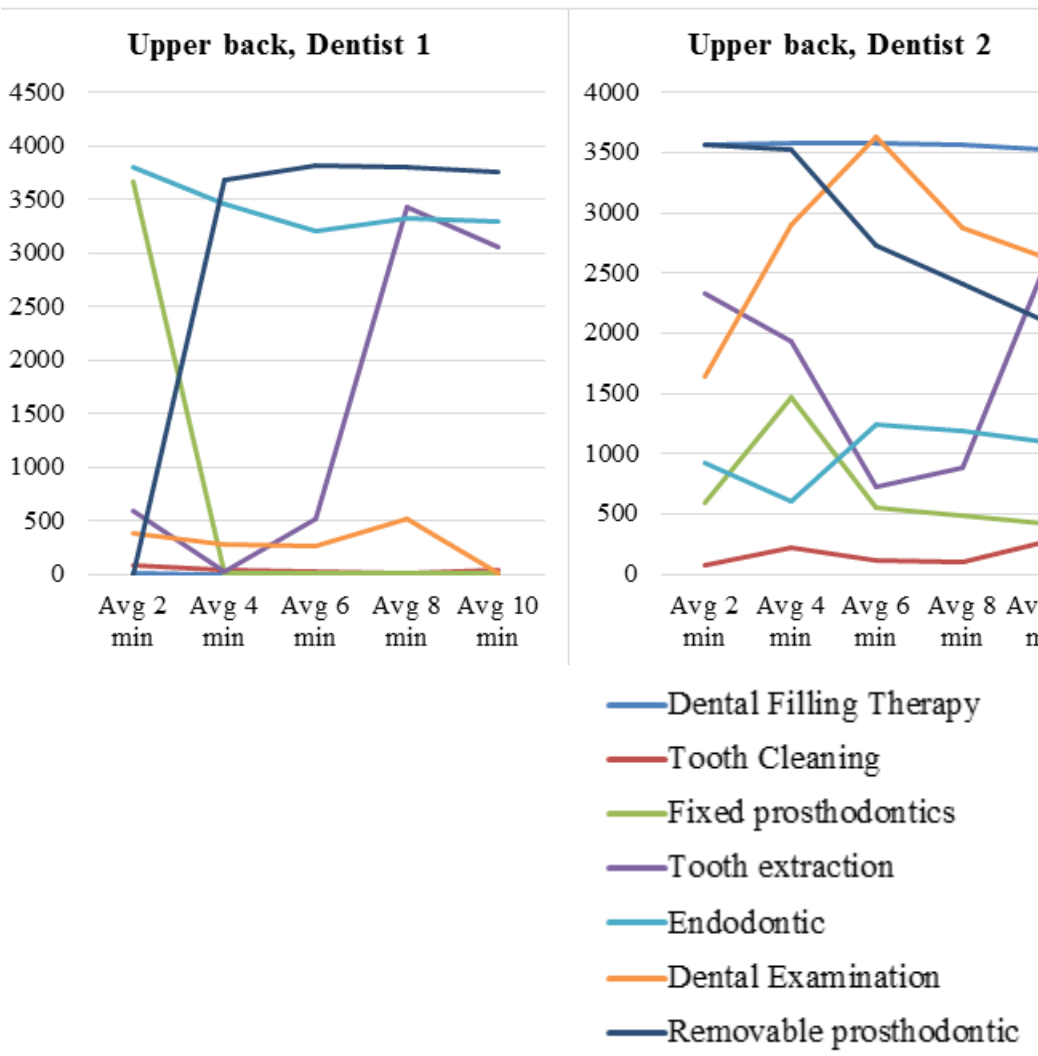

Figure 12: Muscular activities (in $\mu \mathrm{V}$ ) of the 3 dentists at their upper back (rhomboideus major) during most common 7 treatments 
Lower back muscle activities were observed to be fluctuating during removable prosthodontic, dental filling therapy and fixed prosthodontics for the dentist 1 , the dentist 2 , and the dentist 3 respectively (figure 13).
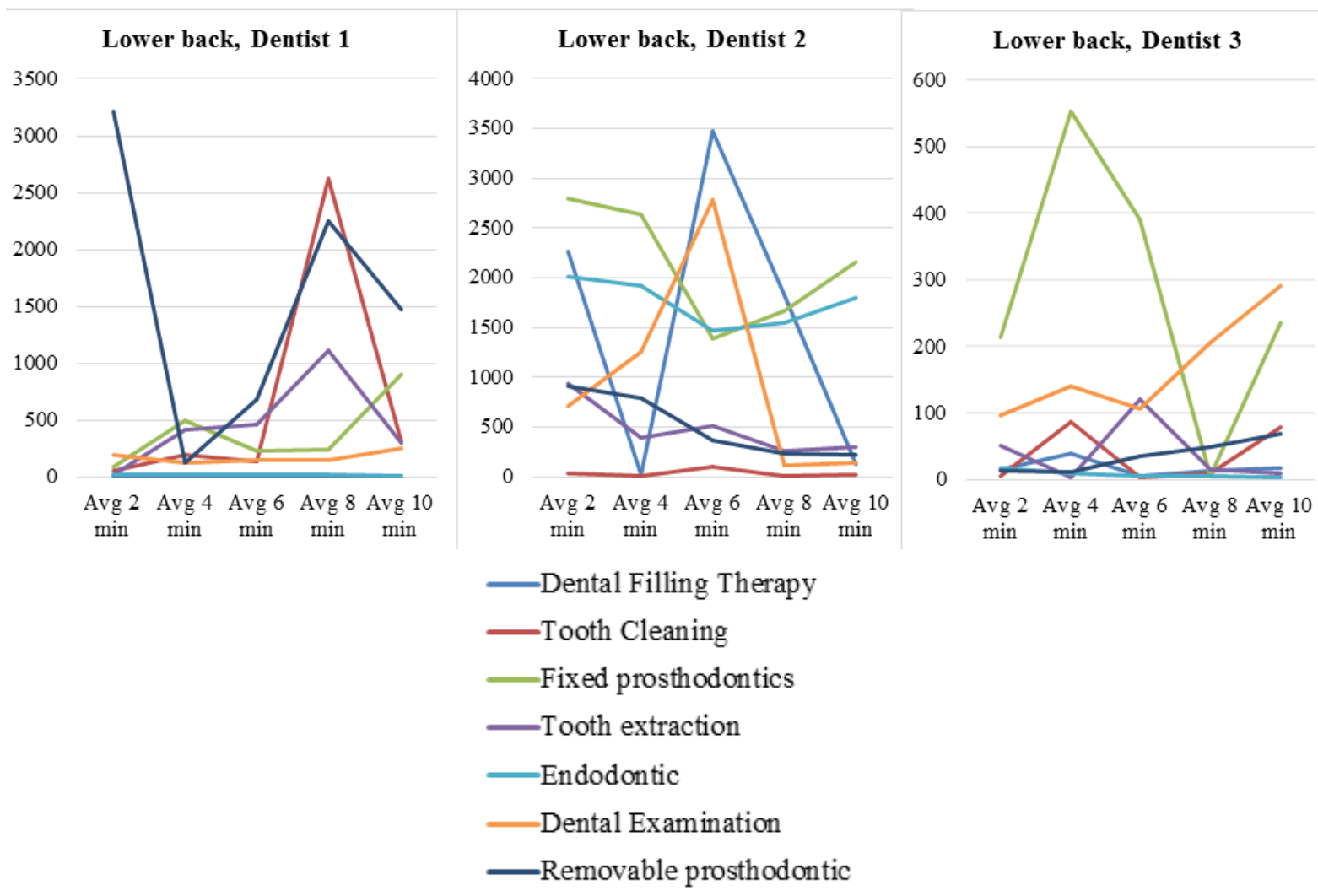

Figure 13: Muscular activities (in $\mu \mathrm{V}$ ) of the 3 dentists at their lower back (sacropinalis) during most common 7 treatments

\subsection{Hypothesis Test Results}

The first hypothesis to be tested by Analysis of Variance (ANOVA) is:

$H_{0}=$ The median frequency (MDF) electrical activity [in time] in the six muscle group does not differ
Table 12 illustrates the hypothesis testing results, where other than tooth cleaning treatment by the dentist 1 , and dental filling therapy and tooth extraction treatments by the dentist 3 , the hypothesis should be rejected.

Table 12: $F_{0}$ values for muscular activity of the 3 dentists during 7 treatments $\left(F_{\text {critical }}=\mathbf{2 . 6 2 0 6 5 4}\right)$

\begin{tabular}{llll}
\hline Treatment & Dentist 1 & Dentist 2 & Dentist 3 \\
\hline Dental Filling Therapy & 2.847302 & 22.33715 & $1.574121^{*}$ \\
Tooth Cleaning & $2.11497^{*}$ & 28.36011 & 3.314879 \\
Fixed Prosthodontics & 8.835778 & 4.224262 & 6.161433 \\
Tooth Extraction & 3.828827 & 5.582777 & $1.476098^{*}$ \\
Endodontic & 21.95 & 21.96567 & 11.30731 \\
Dental Examination & 39.25408 & 3.510959 & 10.01707 \\
Removable Prosthodontic & 6.226711 & 19.27976 & 9.532707 \\
\hline
\end{tabular}


The second hypothesis test, sEMG data used to test the musculoskeletal strains on body regions for three dentists. Muscle strains of all participants were evaluated according to dental tasks separately. Thus;

$$
\mathrm{H}_{0}: \mu_{\mathrm{ijz}}=\mu_{\mathrm{ijz}}
$$

Where;

$\mu_{i j z}$ : The median frequency (MDF) electrical activity in the muscle $\mathrm{i}$, for job j, by dentists $\mathrm{z}$.
Table 13 provides the test result for the second hypothesis in this research. It is observed that there is no significant factor on dental filling therapy, tooth cleaning, fixed prosthodontics, and removable prosthodontics treatments.

Table 13: ANOVA test for the musculoskeletal strains on body regions for three dentists

\begin{tabular}{llll}
\hline \multirow{2}{*}{ Treatment } & \multicolumn{2}{l}{ Source of Variation } & \\
& Body Region & Time & Interaction \\
\hline Dental Filling Therapy & 2.280873 & 0.119247 & 0.692197 \\
Tooth Cleaning & 1.815109 & 0.182608 & 0.587078 \\
Fixed Prosthodontics & 1.493629 & 0.466903 & 0.751724 \\
Tooth Extraction & 2.371747 & 0.231439 & 1.089736 \\
Endodontic & 3.500023 & 0.117128 & 1.045701 \\
Dental Examination & 2.882692 & 0.33121 & 1.237573 \\
Removable Prosthodontic & 2.050677 & 0.187605 & 0.785149 \\
Fcritical & 2.37 & 2.53 & 1.75 \\
\hline
\end{tabular}

However, table 13 provides the results that; body region is the only significant factor on tooth extraction, endodontic and dental examination treatments.

\section{Discussion}

Dentists work in a sitting or standing position. Some of them are working with own assistance which is an effective way to decrease musculoskeletal disorders for dentists. Regarding to their working position, dental personnel can have disorders because of their wrong posture.

Dentists have inflexible and narrow working area (the mouth of the patient). This limited space prevents motions and may cause certain discomforts. These discomforts should be measured in all body parts whether the result cannot be realistic or valid.

This study reveals the musculoskeletal discomfort among dentists during the most common treatments in their profession. In this research, it was very challenging to work with dentists to obtain data for statistical analysis. In order to not violate the rights of patients, patient permission was required to study in working environment.

There are a few studies which show musculoskeletal disorders because of the lack of having correct position while treating. According to Puriene et al. (2008) fatigue (94.7\%) and back pain (91.0\%) were the most prevalent physical complaints reported amongst Lithuanian dentists. Morse et al. (2010) showed that dentists report $26-73 \%$ period prevalence of neck symptoms over the previous year, and 20-65\% with shoulder symptoms.
Sanders and Turcotte (2010) found that dental hygenists suffered from musculoskeletal discomfort in the neck (87\%), upper back (63.3\%), lower back $(63.3 \%)$, shoulders (53\%), and wrists (36.7\%). Our findings also revealed that during the past 12 months; the chronic complaints at the shoulders (68.75\%), neck (64.29\%), and upper back (61.11\%) are the highest perceived discomforts.

However, there is no other research addressing to the risk factors of musculoskeletal discomforts among dentists, the impact of the dental tasks on the body regions during particular treatments.

Besides, this study illustrates that dentists' efficiency is directly proportional with correct posture. Also routine exercise can decrease their pain. If dentists do not pay attention to their posture, WRMSDs and early retirement are inevitable.

\section{Conclusion}

In this research, 67 dentists from Antalya region of Turkey participated in a questionnaire study. Also, three dentists were randomly selected and invited to a sEMG data collection during their professional activities.

Statistics revealed that there were 7 most common dental tasks: dental filling therapy (74.63\%), followed by tooth cleaning (52.24\%), fixed prosthodontics (52.24\%), tooth extraction (47.76\%), endodontic treatment (46.27\%), dental examination (44.78\%), and removable prosthodontics (35.82\%).

Discriminant analysis was applied to the data collected from the questionnaire to find out the significant factors 
which contribute to musculoskeletal discomfort in dentistry. During the past 12 months, physical demands of dental practice work tasks, tress level, taking break between patients, weekly exercise habits, physical demand of hobbies, alcohol consumption, and days worked per week were found to be the significant factors to contribute musculoskeletal discomfort in the body parts. Neck, upper back, lower back, hip/thigh, ankles/feet, and elbows are found to be significantly affected by the family situation. In addition, dental assistant usage is found to be a significant factor to the musculoskeletal discomfort at the hip/thigh, ankles/feet, and elbow region of the dentists.

However, the significant factors to contribute musculoskeletal discomfort in the past 7 days are found to be different. Age, gender, height, weight, and practice years are found to be significantly affected by the body regions. Wrist/hand, shoulder, neck, upper back, lower back, ankles/feet, knees, and elbows are found to be significantly affected by physical demands of dental practice. Working time with patient is found to be a significant factor of the musculoskeletal discomfort at the wrist/hand, shoulder, neck, upper back, lower back, hip/thigh, knees, and elbow regions. Similarly, working hours per week is found to be another significant factor of musculoskeletal discomfort at the wrist/hand, neck, upper back, hips/thigh, knees, ankles/feet, and elbow regions. In addition, area of specialization was found to be affecting wrist/hand, shoulder, neck, knees, and ankles/feet regions. Dental assistant usage was also found to be a significant factor of musculoskeletal discomfort at wrist/hand, neck, and elbow regions.

Hypothesis testing showed that there is no significant factor on dental filling therapy, tooth cleaning, fixed prosthodontics, and removable prosthodontics treatments. However, body region is the only significant factor on tooth extraction, endodontic and dental examination treatments.

\section{Acknowledgement and Competing Interest}

This research was conducted by Ms. Müge Hanefioğlu under the supervision of Assoc. Prof. Dr. Orhan Korhan as a part of the Master's thesis. There no competing interest available within this research. This research did not get any financial support/grant.

\section{Conflict of Interest}

No conflict of interest was declared by the authors.

\section{References}

Åkesson, I., Johnsson, B., Rylander, L., Moritz, U. (1999). Musculoskeletal Disorders Among Female Dental
Personnel - Clinical Examination and A 5-Year Follow-Up Study of Symptoms. Int Arch Occup Environ Health, 72, 395-403.

Åkesson, I., Balogh, I., Hansson, G.A. (2012). Physical Workload in Neck, Shoulders and Wrists/Hands in Dental Hygienists During A Work-Day. Applied Ergonomics, 43, 803-811.

Alexandre, P.C.B., Silva, I.C.M., Souza, L.M.G., Câmara, V.M., Palácios, M., Meyer, A. (2011). Musculoskeletal Disorders Among Brazilian Dentists. Archives of Environmental \& Occupational Health, 66 (4), 231235.

Cherniack MG1, Dussetschleger J, Bjor B. (2010). Musculoskeletal Disease and Disability in Dentists. Work. 35 (4), 411-418.

Dong, H., Loomer, P., Barr, A., LaRoche, C., Young, E., Rempel, D. (2006). The Effect of Tool Handle Shape on Hand Muscle Load and Pinch Force in A Simulated Dental Scaling Task. Applied Ergonomics, 38, 525531.

Finsen, L., Christensen, H., Bakke, M. (1998). Musculoskeletal Disorders Among Dentists and Variation in Dental Work. Applied Ergonomics, 29 (2), 119-125.

Hayes, M.J., Smith, D.R., Taylor, JA (2013). Musculoskeletal Disorders and Symptom Severity Among Australian Dental Hygienists. BMC Research Notes 6 (250), 1-5.

Kar, G., Mullick, A. (2012). Designing With Users: A Case Study For Design of Dental Workspace. Proceedings of the Human Factors and Ergonomics Society 56th Annual Meeting, 56, 652-655.

Khan, S.A., Yee, Chew, K. (2013). Effect of Working Characteristics and Taught Ergonomics on The Prevalence of Musculoskeletal Disorders Amongst Dental Students. BMC Musculoskeletal Disorders. 14 (118), 1-8.

Kuorinka I, Jonsson B, Kilbom A, et al. (1987). Standardized Nordic Questionnaires for The Analysis of Musculoskeletal Symptoms, Applied Ergonomics, 18, 233-237.

Külcü, D.G., Gülșen, G., Altunok, T.Ç., Küçükoğlu, D., Naderi, S. (2010). Neck and Low Back Pain Among Dentistry Staff. Turk J Rheumatol, 25, 122-129.

Leggat P.A., Kedjarune, U., Smith, D.R. (2007) Occupational Health Problems in Modern Dentistry: A Review. Industrial Health, 45 (5), 611-621.

Lin, T., Hsieh, T.Y., Horowitz, A.M., Chen, K.K., Lin, S.S., Lai, Y.J., Hsiao, F.Y., Chang, C.S. (2012). Prevalence of and Risk Factors for Musculoskeletal Complaints Among Taiwanese Dentists. Journal of Dental Science, 7, 65-71. 
Madaan, V., Chaudhari, A. (2012). Prevalence and Risk Factor Associated With Musculoskeletal Pain Among Students on MGM Dental College: A Cross- Sectional Survey. Journal of Contemporary Dentistry, 2 (2), 2227.

Morse T, Bruneau H, Dussetschleger J. (2010). Musculoskeletal Disorders of The Neck And Shoulder in The Dental Professions. Work, 35 (4), 419-429.

Nutalapati, R., Gaddipati, R., Chitta, H., Pinninti, M., Boyapati, R. (2009). Ergonomics in Dentistry and the Prevention of Musculoskeletal Disorders in Dentists. The internet journal of occupational health, 1 (1).

Patel, H.L., Marwadi, M.R., Mihir, R., Piyanka, P. (2012). Prevalence and Associated Factors of Back Pain Among Dentists in South Gujarat. National Journal of Medical Research, 2 (2), 229-231.

Puriene, A., Aleksejuniene, J., Petrauskiene, J. (2008). Balciuniene, I., Janulyte, V. Self-reported Occupational Health Issues Among Lithuanian Dentists. Industiral Health. 46 (4), 369-374.

Rabiei, M., Shakiba, M., Shahreza, H.D., Talebzadeh, M. (2012). Musculoskeletal Disorders in Dentists. International Journal of Occupational Hygiene by Iranian Occupational Health Association (IOHA) IIJOH, 4, 36-40.

Rolander B, Karsznia A, Jonker D, Oberg T, Bellner AL (2005). Perceived Contra Observed Physical Work Load in Swedish Dentists. Work, 25(3), 253-262.

Sanders MJ, Turcotte CM (2010). Occupational Stress in Dental Hygienists. Work, 35 (4): 455-465.

Thanathornwong, B., Suebnukarn, S., Songpaisan, Y., Ouivirach, K (2012). A System for Predicting and Preventing Work-Related Musculoskeletal Disorders Among Dentists. Computer Methods in Biomechanics and Biomedical Engineering, 17 (2), 177-185.

Yousef, M.K., Al-Zain, A.O. (2009). Posture Evaluation of Dental Students. JKAU, Med. Sci.; 16 (2), 51-67.

Zoidaki, A., Riza, E., Kastania, A., Papadimitriou, E., Linos, A. (2011) Musculoskeletal Disorders Among Dentists in The Greater Athens Area, Greece: Risk Factors and Correlations. J Public Health, 3 (21), 163-173. 